Gwen Brekelmans*

Radboud University

University College London
UDK 811.111'34:37.091.3

DOI: 10.4312/linguistica.57.1.45-58

\title{
THE VALUE OF PHONETICS AND PRONUNCIATION TEACHING FOR ADVANCED LEARNERS OF ENGLISH
}

\section{INTRODUCTION}

Pronunciation tends to take a back seat in both second language acquisition research and secondary and higher education all over the world (Underhill 2013). When learners study English at university, however, they generally receive proper pronunciation coaching, which can help them acquire a more native-like pronunciation. Once they have acquired this, however, the challenge is maintaining it. This study explored how learners go about maintaining their pronunciation by investigating the influence of the discontinuation of pronunciation teaching on the upkeep of a near-native accent, based on an RP pronunciation model, in advanced Dutch learners of English.

In particular, this study investigated whether the English pronunciation of those advanced Dutch learners improved, deteriorated, or remained stable over time once explicit pronunciation had ceased, by means of a longitudinal study of the speech of Dutch university students who were studying English. The speech of a cohort of learners was sampled at several points during their undergraduate degree by means of making audio recordings of several tasks; importantly, the explicit phonetics and RP pronunciation instruction they received during their degree stopped after the second year. The main sub-questions that were investigated were, therefore, whether degree year and task type were of any influence on the learners' pronunciation. This study also explored any possibly confounding influence of the amount of exposure to English learners received by taking into account the number of English-taught courses that they took during their undergraduate degree, and whether they spent a term abroad in an English-speaking country. The hypothesis was that the pronunciation of third-year students would become less native-like than it was before, with their pronunciation not being as native-like as it was at the end of the second year, but more native-like than at the end of the first year. Read speech was expected to be more native-like in pronunciation than spontaneous speech, and the possible confounder of having more exposure to English in general, whether through courses or going abroad, was expected to have a positive influence on the students' pronunciation.

In attaining L2 proficiency, even relatively limited explicit instruction has been shown to be beneficial to a learner's pronunciation. Lord (2005) and Lipinska (2013) found that explicitly teaching segmental phonetics improved learners' production, while

* gwen.brekelmans.15@ucl.ac.uk 
Kennedy, Blanchet and Trofimovich (2013) showed that after a short course focussing on suprasegmentals, learners of French only improved their segmental and not their suprasegmental production while their perception improved overall, indicating that it might take longer for perception to extend into all aspects of production. This matches the results from Saito (2011), who found that learners' comprehensibility improved significantly after as little as four hours of phonetic instruction, while their accentedness did not change. He thus demonstrated that some but not all aspects of production showed signs of improvement after a short period of instruction. Gordon, Darcy and Ewert (2013) added to this by showing that a more intensive three-week pronunciation course resulted in significant improvements when learners were explicitly taught about both segmentals and suprasegmentals. In compiling an overview of similar studies investigating the effects of explicit instruction on L2 pronunciation, Saito (2012) found that most studies showed that learners improved significantly after receiving explicit instruction. Interestingly, all of these works showed improvements in controlled speech, but indicated that spontaneous speech required more specific teaching methods.

A commonly held idea is that learners' pronunciation will improve as long as they practise both in and outside of the classroom. Szpyra-Kozlowska (2015) added to this by stating that nowadays, with limited time dedicated to teaching pronunciation, individual learning is a vital part of acquiring L2 pronunciation. Grant (2014) argued against the idea that practice alone will determine a learner's level of pronunciation, and stated that individual learner characteristics were much more influential: the learner's L1 and the amount of exposure to the L2 were especially important. In line with this idea, Iverson and Evans (2007) demonstrated that having a larger vowel inventory in the L1 than in the L2 was more beneficial to acquiring the vowel system than vice versa, as the former would result in separate mappings of L2 vowels onto L1 vowels, while the latter resulted in overlaps. Exposure to the L1 has also been shown to have a direct influence: increased L1 use can have a negative effect on a learner's accentedness (Flege/Frieda/Nozawa 1997), as can a continued use of the L1 when compared to learners who no longer use the L1 at all (Piske/MacKay/Flege 2001).

Another possibly influential factor is best described by accommodation theory. As first described by Giles (1973), two speakers can adapt their speech to each other to sound more similar. This convergence is often used as a means of gaining social approval (Coupland 2010), as speakers tend to converge to those people they like or admire. Divergence, on the other hand, is used to create distance between speakers. In this study, accommodation theory could explain the potential changes in participants' pronunciation. While there is no direct communication with another speaker in the recording itself, participants are aware the recordings will only be listened to by the pronunciation teacher, a speaker of RP. This means she is their target audience, opening up the possibility of there being convergence, in particular for their speech in response to open questions. After explicit instruction is stopped, there are essentially three ways in which the participants' pronunciation might develop: it could remain on the same level as it was before, it could improve and come to sound more RP-like, or it could deteriorate and become more Dutch. If the students' pronunciation were to 
remain at a similar level as it was before, this would indicate that it has become stable. If it were to revert to a more Dutch variant, this stability would not have been achieved yet, while if it were to become more RP-like this would indicate they have achieved a level of awareness that enables them to improve their pronunciation without explicit feedback. Key to accommodation theory is that convergence tends to occur when people want to converge (Byrne 1971; Pardo et al. 2012). In the case of these participants, it is unlikely that they would want to sound more Dutch, indicating that any change towards Dutch was not a conscious decision to converge. Instead, if any conscious convergence took place, the participants would likely want to sound more like native speakers. It is important to note that while the participants chose the British pronunciation track, and thus chose to study RP instead of General American, their answers to what they thought of their pronunciation indicated that they valued sounding nativelike, though none of them stated they necessarily wanted to sound fully RP-like. It should, therefore, be taken into account that the motivation to sound RP-like might not have been as high as the motivation to sound more generally native-like, leading to the possibility of the participants converging to a preferred variety of British English, and not to RP English in particular.

\section{METHODOLOGY}

In order to investigate the pronunciation stability of advanced learners of English, recordings were made of Dutch undergraduate students of English. These recordings were made in their third year, and were compared to existing recordings of the same students made during pronunciation exams in the first and second years, after which the students' pronunciation was analysed and rated for RP-like-ness in three different task types on the basis of a set of pronunciation features.

\subsection{Participants}

Twelve native Dutch learners of English voluntarily participated in the study. Their mean age was 22 years $(\mathrm{SD}=1.7)$. These learners were third-year undergraduates of English at Radboud University Nijmegen, had all chosen the British English pronunciation track, and came from the same cohort that started their degrees in 2012. Importantly, all participants were in their third year, as at Radboud University undergraduate students of English in this year no longer receive courses in phonetics or pronunciation, while they do in the first and second years. During those previous two years, the students received weekly pronunciation training sessions consisting of drills as well as listening and imitation, and they received additional weekly training in basic articulatory phonetics during their first year.

In addition to no longer receiving explicit instruction in pronunciation and phonetics, the third-year students also have a varying number of English-taught courses: in their third year, the programme mainly consists of electives and these could be in either English or Dutch (Studiegids Engels) depending on individual choices. These electives are often offered by different departments than the English one, and thus it is much less likely that the lecturers are using RP in their teaching, if they are even taught in 
English at all. In contrast, the first and second years have a fixed number of courses taught in English for all students: in year 1, 55 ECTS are English-taught, while in year 245 ECTS are taught in English. The varying number of English-taught courses in the students' third year could thus be a potentially influential confounding variable on the overall RP-like score, with more courses possibly leading to a higher score.

A third of the participants spent the first term of their third year abroad in England (three participants) or Ireland (one participant). During this term they would have had an increased amount of exposure to English, which could mean that participants who spent time abroad outperform their peers who did not go abroad. While this exposure might not necessarily have been to RP English, it could still have had a beneficial effect on their pronunciation: the features on which the students' pronunciation was judged were not always specific to RP English only, as some were particularly focussed on not sounding Dutch. For example, all three participants who spent time in England attended universities in largely non-rhotic areas of the country, and while there might have been slight differences in the exact use depending on the area, all four participants would have come across native speakers using weak forms in their speech. This means that other native varieties of English that they might have come into contact with could have contributed to an improvement in some of the features of their pronunciation. As such, time abroad was considered a possibly influential confounding variable in the analysis.

\subsection{Materials}

Participants were given three tasks to record, designed to elicit both read speech and more spontaneous speech to be able to investigate the task-specific effects of speech style. The first task was reading a phonetically balanced text familiar to the students from previous exams ("Arthur the Rat"). The second task consisted of a set of ten sentences also used in pronunciation exams; each sentence contained features of RP English that are particularly tricky for Dutch learners (e.g. The first few moves looked good for the difference between the vowels /u:/ and /v/). Finally, the third task consisted of three open questions about the students' thoughts on their courses, their pronunciation, and time they spent abroad, which provided useful background information for the analysis.

The process of recording was identical to the procedure during the undergraduate pronunciation exams to minimise differences in the recording setting. The recordings were then compared to previous recordings of the same set of students made during the pronunciation exams of the previous two years. The materials used in the new recordings only differed from the pronunciation exams in the content of the open questions.

\subsection{Procedure}

The recordings took place in the language lab at Radboud University in a setting identical to the exam recordings. However, no more than five students were recorded each session, as pilot recordings revealed having more students in the room to be distracting. 
This differed from the exam recordings, as those were recorded with 20 students in each session due to time constraints.

During the session, participants were seated at a desktop computer with a headset. They were provided with the recording sheet, and were asked to perform the tasks while speaking naturally. There were no time constraints on any of the tasks. Because of the similarity to previous exams, it was stressed their performance would not influence their undergraduate results. After recording, the participants were provided with a brief background questionnaire. In total, the recording session took approximately ten minutes.

\subsection{Analysis}

Recordings were analysed based on a list of features of RP pronunciation used to grade students' pronunciation exams, as shown in Table 1. The list, developed by the pronunciation teacher at Radboud University, focusses on those features that are difficult for advanced Dutch learners of English to master (Hedy Kamara, personal communication, 19 February 2015). For this reason, these features are dealt with extensively during phonetics and pronunciation classes, mostly using Gussenhoven and Broeders (1997).

In acquiring an RP-like accent, the participants learnt about the differences between English and Dutch. Clear differences are found in the vowel inventories: some vowels, such as /e/, have a slightly different position in English than in Dutch, while others, such as /æ/, do not have a Dutch equivalent at all (Collins/Mees 2003). The English consonant inventory is more similar to Dutch than its vowel inventory, but the dental fricatives $/ \theta /$ and $/ \delta /$ do not occur in Dutch at all, while phonemes such as such as $/ \mathrm{g} /$ and /3/ only occur marginally, and may cause problems for Dutch learners. Some of the English consonants, while similar in nature to their Dutch equivalents, differ in the precise manner of articulation, leading to potential obstacles, such as the contrast between $/ \mathrm{f} /$ and $/ \mathrm{v} /$, or $/ \mathrm{s} /$ and $/ \mathrm{z} /$.

There are also several important speech processes that differ between the two languages. Dutch does not have a syllable-final contrast between fortis and lenis consonants (commonly referred to as 'final devoicing'), while English does, so learners need to learn to make this distinction, in particular in the energy of articulation and in the length of the voiced portion. Importantly, Broersma (2005) showed that Dutch learners are able to categorise these English final consonants in a native-like manner while not producing them as such themselves. English voiceless stops are aspirated in onset and preglottalised before consonants in coda, neither of which happen in Dutch (Gussenhoven/Broeders 1997), so this needs to be learnt. These processes are essential for learners to acquire, as Cruttenden (2008) argued that the use of aspiration is even more important than the presence or absence of voicing, as it is a stronger cue for differentiating phonemes in English.

Finally, prosody differences may also be problematic. Using incorrect stress patterns can cause communication to break down, as shown in Reinisch and Weber (2012), among others. In combination with stress patterns, the correct use of weak forms is crucial for a proper understanding, especially in fast speech (Cruttenden 2008). Finally, English has a wider pitch range than Dutch, and this might be difficult for learners to 
learn, as it is known that they tend to compress their pitch range when speaking a foreign language (Collins et al. 2011).

Table 1: List of RP pronunciation features used to analyse the participants' pronunciation.

\begin{tabular}{|c|c|c|c|}
\hline Feature & $\begin{array}{l}\text { Specific difficulty for } \\
\text { Dutch learners }\end{array}$ & $\begin{array}{l}\text { Example of Dutch } \\
\text { error }\end{array}$ & $\begin{array}{l}\text { Means of } \\
\text { analysis }\end{array}$ \\
\hline vowel quality & $/ \mathfrak{x}, \cup, \Lambda, \mathfrak{p}$, ৩: ও:/ & $/ \mathfrak{x} /$ realised as $[\varepsilon]$ & $\begin{array}{l}\text { auditory \& } \\
\text { acoustic }\end{array}$ \\
\hline word and sentence stress & compounds & $\begin{array}{l}\text { /lei 'aut/ for /'leI } \\
\text { aut/ }\end{array}$ & auditory \\
\hline $\begin{array}{l}\text { duration of voiced } \\
\text { portions }\end{array}$ & $\begin{array}{l}\text { voiced portion length be- } \\
\text { fore fortis vs. lenis endings }\end{array}$ & $\begin{array}{l}\text { same VP for /bit/ } \\
\text { and /bid/ }\end{array}$ & $\begin{array}{l}\text { auditory \& } \\
\text { acoustic }\end{array}$ \\
\hline consonants & $\begin{array}{l}\text { articulation of } / \theta, \mathrm{\partial} / \\
/ \mathrm{s} / \mathrm{vs} / \mathrm{z} / \\
\text { /f/ vs. } / \mathrm{v} / \\
\text { final devoicing } \\
\text { initial devoicing }\end{array}$ & $\begin{array}{l}\text { /tri/ for / } \theta \text { rii/ } \\
\text { /bet/ for /bed/ }\end{array}$ & acoustic \\
\hline voiceless stops & $\begin{array}{l}\text { aspiration } \\
\text { preglottalisation }\end{array}$ & [pit] for $\left[\mathrm{p}^{\mathrm{h}} \mathrm{It}\right]$ & acoustic \\
\hline non-rhoticity & distribution of $/ \mathrm{r} /$ & /fa:r/ for /fa:/ & auditory \\
\hline undesirable assimilations & $\begin{array}{l}\text { regressive voicing } / \mathrm{b}, \mathrm{d} / \\
\text { progressive voicing } / \mathrm{v}, \mathrm{z} / \\
\text { intervocalic voicing }\end{array}$ & $\begin{array}{l}\text { /'fu:dbo:1/ for / } \\
\text { 'fu:tbo:1/ }\end{array}$ & acoustic \\
\hline strong vs. weak forms & lack of weak forms & $/$ /ænd/ for /ən $(\mathrm{d}) /$ & auditory \\
\hline liaison & $\begin{array}{l}\text { overuse of glottal stop for } \\
\text { unemphasised speech }\end{array}$ & $\begin{array}{l}\text { [ond ?ar] for [ənd } \\
\text { aI] }\end{array}$ & acoustic \\
\hline intonation & $\begin{array}{l}\text { flat intonation } \\
\text { overuse of rising terminal }\end{array}$ & uptalk & $\begin{array}{l}\text { auditory \& } \\
\text { acoustic }\end{array}$ \\
\hline
\end{tabular}

Each of the features was analysed either auditorily or acoustically using Praat (Boersma/Weenink 2015), or both, as indicated in Table 1. For each feature, the author determined an RP-likeness score based on the percentage at which the participant produced the feature in an RP-like manner. These individual scores were collated to compare within and between participants over the years, and to see if there was a difference between task types and features. For the purpose of this study, all features contributed equally to the final RP-like score, though in reality certain features of Dutch-accented English are more detrimental to communication and are rated more negatively by native speakers than others (van den Doel 2006; Koet 2007). 


\section{RESULTS}

\subsection{Influence of Year and Task Type}

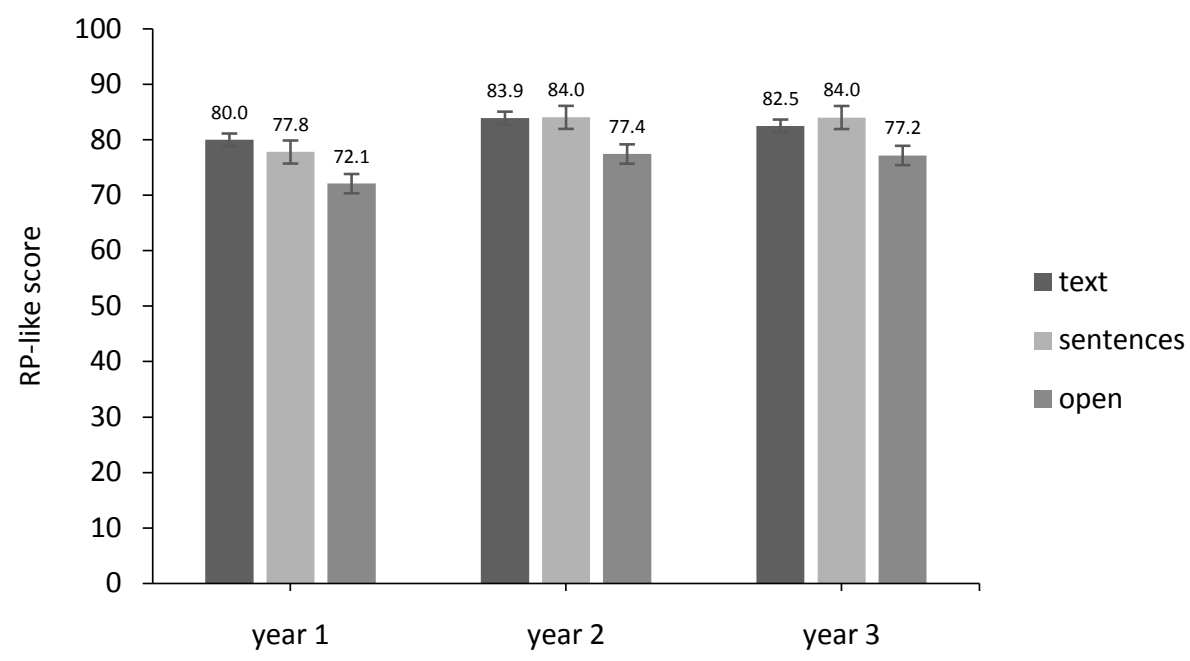

Figure 1: The overall RP-like score per task type, shown for each year. Error bars show two standard deviations from the mean.

A 3 by 3 repeated measures ANOVA was performed to investigate the effects of year and task type on the participants' RP-like score. The results of the ANOVA show that there was a significant main effect of task, with the RP-like score being significantly affected by the type of task that was being performed, $F(2,22)=17.24, p<.001$. There was also a main effect of year, with the year of study the recording was made in significantly influencing the RP-like score, $F(2,22)=18.12, p<.001$. However, there was no significant interaction between task type and year of study, indicating that the participants showed similar patterns of performance on the different tasks throughout their studies, $F(4,44)=1.19, p=.33$. This pattern can be seen in Figure 1, which shows that in all three years the participants received a lower RP-like score for the open questions than they did for the other two tasks.

Post-hoc Bonferroni pairwise comparisons showed that for task type the RP-like score for the open questions $(\mathrm{M}=75.58, \mathrm{SD} 2.01)$ was significantly lower than for both the read text $(\mathrm{M}=82.12$, SD 1.98; Bonferroni $-6.56 \pm 1.17$ points, $p<.001)$ and sentences $(\mathrm{M}=81.94$, SD 2.09; Bonferroni $-6.38 \pm 1.47$ points, $p=.003)$. However, the read text and sentences did not differ significantly in RP-like scores $(0.174 \pm 1.16$ points, $p=1.00$ ).

For the year of recording, a post-hoc Bonferroni pairwise comparison revealed that the RP-like score in year $1(\mathrm{M}=76.63, \mathrm{SD} 2.17)$ was significantly lower than it was in year $2(\mathrm{M}=81.77$, SD 1.85; Bonferroni $-5.14 \pm 1.11$ points, $p=.002)$ and year $3(\mathrm{M}$ $=81.23$, SD 1.86; Bonferroni $-4.60 \pm 1.04$ points, $p=.003)$, but that the difference in $\mathrm{RP}-$ like score for years 2 and 3 was not significant $(0.54 \pm 0.56, p=1.00)$. 
A further look at the data showed that the different features and subfeatures did not develop in the same way over time. Vowel quality and liaison generally seem to be difficult for the participants, as the percentages for these features remain relatively low. Strikingly low scores occur for subfeatures that are notoriously difficult for Dutch learners of English (Collins/Mees 2003), in particular the TRAP vowel (which peaks at 58\% in year 2), dental fricatives (starting at 67\% and declining), and preglottalisation (starting at $65 \%$ and declining to $49 \%$ by year 3 ). These learners still struggle with these features in their third year of studying English, even though they are considered advanced learners, and in fact partially deteriorate for these specific features. However, they seem to pick up other features more quickly, in particular stress patterns (around 98\% throughout) and rhoticity (the lowest score being at $90 \%$ ), as performance is near ceiling even in their first year and they remain stable throughout. In comparison, other features, such as the various vowels, are much more variable over time.

\subsection{Influences of Confounding Variables: Exposure to English}

To find out if variation in the amount of exposure to English played a confounding role in any change in the participants' pronunciation, a regression model was fitted to the data in which the confound was taken into account. The possible confounding influence on the overall RP-like scores of the participants was split up into two parts: the influence of studying abroad and the number of English-taught courses taken during the third year. In the model, the independent variables had to be entered separately from the confounding variables, so a hierarchical regression was chosen. In the first step, year of study was controlled for, as well as the task type, and the specific feature (e.g. vowel quality, rhoticity) and subfeature (e.g. aspiration, intervocalic voicing of voiceless consonants). Section 3.1 showed that these factors played an important part in the RP-like score, so they were controlled for to find out whether in step two the number of courses and time spent abroad improved the model's prediction of the participants' scores.

As seen in Table 2, below, the model that controlled for year of study, task type, and pronunciation feature explained $3.3 \%$ of the variance in the data. Adding the number of courses and time spent abroad to the model resulted in a significant $\mathrm{R}^{2}$ change $=0.003$, $p=.014$. Interestingly, the factors only explained a very small part of the variance, even though the models were a good fit to the data, as the p-values of the regression ANOVA are all $p<.001$. Cook's distance showed there were no influential outliers in the model, and there was no multicollinearity.

As can be seen in step 2 of Table 2, the number of English-taught courses a participant took in their third year was a significant predictor of their RP-like score when controlling for year, task type, feature, and subfeature, but time spent abroad did not significantly add to the fit of the model. When inspecting the data more closely, see Figure 3, there does seem to be a trend for participants who went abroad to continue increasing their RP-like score even after explicit instruction was stopped, but the difference is very small and not significant. 
Table 2: Linear model of predictors for RP-like score, with 95\% CI in parentheses $(b=$ unstandardized coefficient; SE B = standard error of $\mathrm{b} ; \beta=$ standardised coefficient).

\begin{tabular}{|c|c|c|c|c|}
\hline & $\mathrm{b}$ & SE B & $\beta$ & $p$ \\
\hline \multicolumn{5}{|l|}{ Step 1} \\
\hline Constant & $87.883(84.060,91.707)$ & 1.950 & & \\
\hline Year of study & $2.319(1.313,3.324)$ & 0.513 & .088 & .000 \\
\hline Task type & $-3.060(-4.069,-2.051)$ & 0.514 & -.116 & .000 \\
\hline Feature & $-1.081(-1.467,-0.695)$ & 0.179 & -.113 & .000 \\
\hline Subfeature & $-0.104(-0.200,-0.009)$ & 0.049 & -.044 & .033 \\
\hline \multicolumn{5}{|l|}{ Step 2} \\
\hline Constant & $91.104(86.556,95.653)$ & 2.320 & & \\
\hline Year of study & $2.315(1.311,3.319)$ & 0.512 & .088 & .000 \\
\hline Task type & $-3.060(-4.067,-2.053)$ & 0.514 & -.113 & .000 \\
\hline Feature & $-1.081(-1.466,-0.696)$ & 0.197 & -.113 & .000 \\
\hline Subfeature & $-0.104(-0.200,-0.009)$ & 0.049 & -.044 & .033 \\
\hline Number of English-taught courses & $-0.540(-0.916,-0.164)$ & 0.192 & -.056 & .005 \\
\hline Time spent abroad & $0.052(-0.390,0.495)$ & 0.225 & .005 & .816 \\
\hline
\end{tabular}

Note: $\mathrm{R}^{2}=0.033$ for step $1 ; \Delta \mathrm{R}^{2}=0.003$ for step $2(p=.014)$.

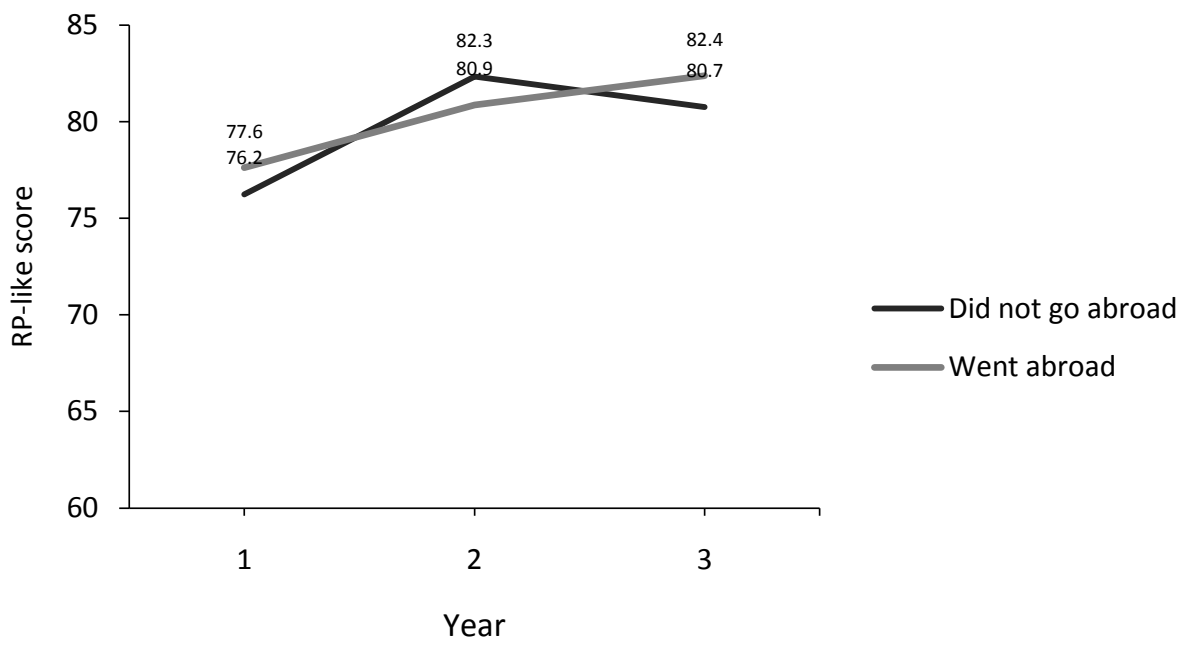

Figure 3: Average RP-like score per year for the participants who went abroad and those who did not. Score out of 100 .

\section{DISCUSSION}

This study investigated whether the English pronunciation of advanced Dutch learners improved, deteriorated, or remained stable over time once explicit pronunciation had 
ceased. Sub-questions to this main research question were whether there was any influence of the degree year the learners were in and the task they were asked to perform, as well as whether there was any confounding influence of the varying levels of exposure to English due to different courses and spending time abroad. It was hypothesised that after pronunciation teaching had stopped, the learners' pronunciation would deteriorate over time. Additionally, read speech was thought to be more native-like than spontaneous speech, and an increased exposure to English in general was thought to have a positive confounding influence on learners' pronunciation.

\subsection{Effects of Year and Task Type}

The results show that the year in which the participants were recorded had a clear influence on their RP-like score. In the first year the participants were least RP-like, but they improved from the first to the second year. However, unexpectedly, once explicit phonetics and pronunciation teaching was stopped, the participants did not change significantly in their RP-like score and the expected deterioration was not found. It seems that the participants' pronunciation was thus stable enough to remain on the same level even without instruction. Importantly, however, the score did not improve in the third year. This means that there was no clear evidence of a long-term effect of convergence in either direction, even though possible motivations to converge to either English native speakers or Dutch speakers were present (Coupland 2010).

Strikingly, not all features developed in the same way over time. Some features seemed more robust than others, and remained stable throughout, while others appeared more difficult. A feature consistently low in its RP-like score was liaison, which is not present in Dutch: where Dutch inserts a glottal stop at the beginning of words, English connects them (Gussenhoven/Broeders 1997). Subfeatures that remained low throughout were those that are notoriously difficult for Dutch learners: dental fricatives $/ \theta /$ and $/ ð /$, which tend to be stopped, and the TRAP vowel/æ/, which is usually replaced by Dutch $/ \varepsilon /$ (Collins/Mees 2003). Conversely, features that were picked up relatively quickly, such as stress patterns and rhoticity, tend to be rule-governed in their realisation, making it easier to acquire them (Gussenhoven/Broeders 1997).

In addition to a difference through the years, there was also a clear task effect: participants were less RP-like in their pronunciation for the open questions than for the read text and sentences. This is likely due to task demands: the open questions not only required the participants to speak English, but they also had to come up with an answer on the spot. This means that their cognitive load would have been higher than in the other two tasks, where they only had to read out a text or sentences, and they would likely have focussed less on their pronunciation.

\subsection{Confounding Variables: Exposure to English}

The regression model showed that, when controlling for the independent variables, the number of courses a participant took in their third year was a significant predictor of their RP-like score, while spending a term abroad was not. The controlled factors 
explained $3.3 \%$ of the variation in the data, with number of courses explaining an additional $.3 \%$ of the variation. Remarkably, the number of courses a participant took was a significant influence on their RP-like score, while in the third year none of the courses explicitly taught pronunciation or phonetics. Moreover, not all courses the students took were taught by speakers of RP, so there would not always be a direct benefit from the increased input. Since the participants still benefited from the increase in exposure, this seems to support Grant (2014) in the claim that more L2 exposure is beneficial to pronunciation, though it remains to be seen how much of this benefit truly adds to the accent quality, as it has mainly been shown to relate to fluency and general comprehensibility.

Whether participants spent time abroad did not significantly influence their RPlike scores. This might be because the additional exposure was mostly in areas that might not have helped much in these tasks: the participants might have developed their interaction skills by talking to native speakers, the majority of whom might not have spoken RP, as well as by talking to non-native speakers. However, the tasks used in this study did not involve any direct interaction. It is quite possible that their pronunciation skills in reading out loud would not have benefited enough from the general increased English exposure to improve. Moreover, it is very plausible that the participants' pronunciation became more native-like while not necessarily becoming more RP-like, and the participants might have picked up features of other native English varieties through coming into contact with speakers from various areas. While this could potentially explain changes in the participants' pronunciation, it was beyond the scope of this study to investigate this in more detail.

\section{CONCLUSION}

Overall, and contrary to expectation, this study showed that for the investigated cohort of advanced Dutch learners of English, discontinuing explicit pronunciation teaching was not a significant influence on the maintenance of a near-native accent. It seems that the instruction they received before teaching was discontinued was enough to allow the learners to achieve a stable pronunciation level. The amount of exposure the learners received turned out to be a confounding influence: when participants took more English-taught courses, their pronunciation was more RP-like. A stay abroad, however, did not affect their performance. The value of pronunciation teaching thus seems to be quite high for advanced Dutch learners of English, as they improved during the first years when they received explicit instruction, but once they managed to reach a certain level it seemed that their pronunciation managed to stabilise enough for them to maintain it without receiving any further such instruction. 


\section{References}

BOERSMA, Paul/David WEENINK (2015) Praat: doing phonetics by computer [Computer program]. Version 5.4.04. http://praat.org/

BROERSMA, Mirjam (2005) Phonetic and lexical processing in a second language. Doctoral dissertation. Nijmegen: Max Planck Institute for Psycholinguistics.

BYRNE, Donn (1971) The attraction paradigm. New York: Academic Press.

COLLINS, Beverley/S.P. DEN HOLLANDER/Inger MEES/Jill RODD (2011) Sounding better: a practical guide to English pronunciation for speakers of Dutch. Holten: Walvaboek.

COLLINS, Beverley/Inger MEES (2003) The phonetics of English and Dutch. Leiden: Brill. COUPLAND, Nikolas (2010) “Accommodation theory.” In: J. Jaspers/J. Verschueren/J. Östman (eds), Society and Language Use. Amsterdam: John Benjamins, 21-27.

CRUTTENDEN, Alan (2008) Gimson's pronunciation of English. (Seventh edition). London: Hodder Education.

DOEL, Rias van den (2006) How friendly are the natives? An evaluation of nativespeaker judgements of foreign-accented British and American English. Doctoral dissertation. Utrecht: Utrecht University.

FLEGE, James/Elaina FRIEDA/Takeshi NOZAWA (1997) "Amount of native-language (L1) use affects the pronunciation of an L2." Journal of Phonetics 25, 169186. http://dx.doi.org/10.1006/jpho.1996.0040

GILES, Howard (1973) "Accent mobility: a model and some data." Anthropological Linguistics 15, 87-105. http://dx.doi.org/10.1177/0261927X8763007

GORDON, Joshua/Isabelle DARCY/ Doreen EWERT (2013) "Pronunciation teaching and learning: effects of explicit phonetic instruction in the L2 classroom." In: J. Levis/K. LeVelle (eds), Proceedings of the 4th Pronunciation in Second Language Learning and Teaching Conference. Aug. 2012. Ames, IA: Iowa State University, 194-206. http://jlevis.public.iastate.edu/pslltconference/4th\%20Proceedings/

GRANT, Linda (2014) "Myth 5: students would make better progress in pronunciation if they just practiced more.” In: L. Grant (ed.), Pronunciation myths: Applying second language research to classroom teaching. Michigan: University of Michigan Press, 137-159.

GUSSENHOVEN, Carlos/Anton BROEDERS (1997) English pronunciation for student teachers. Groningen: Wolters-Noordhoff.

IVERSON, Paul/Bronwen EVANS (2007) "Learning English vowels with different first-language vowel systems: perception of formant targets, formant movement, and duration." Journal of the Acoustical Society of America 122/5, 2842-2854. http://dx.doi.org/10.1121/1.2783198

KELLY, L.G (1969) 25 centuries of language teaching: 500 BC-1969. Rowley, MA: Newbury House Publishers.

KENNEDY, Sara/Josée BLANCHET/Pavel TROFIMOVICH (2013) “L2 learners' speech after French phonetics teaching." In: J. Przedlacka/J. Maidment/M. Ashby (eds), Proceedings of the Phonetics Teaching and Learning Conference, UCL, London, 8-10 August 2013. London: Phonetics Teaching and Learning Conference, 43-46. http://www. ucl.ac.uk/pals/study/cpd/cpd-courses/ptlc/proceedings_2013/proceedings_2013.pdf 
KOET, Ton (2007) Polder English in Dutch ears: empirical studies on the evaluation of the pronunciation of English as a foreign language. Doctoral dissertation. Amsterdam: University of Amsterdam.

LIPINSKA, Dorota (2013) "Influence of formal instruction in English phonetics and phonology on Polish learners' production of English /TRAP/." In: J. Przedlacka/J. Maidment/M. Ashby (eds), Proceedings of the Phonetics Teaching and Learning Conference, UCL, London, 8-10 August 2013. London: Phonetics Teaching and Learning Conference, 59-62. http://www.ucl.ac.uk/pals/study/cpd/cpd-courses/ ptlc/proceedings_2013/proceedings_2013.pdf

LORD, Gillian (2005) "(How) can we teach foreign language production? On the effects of a Spanish phonetics course." Hispania 88/3, 557-567. http://www.jstor.org/ stable/20063159

PARDO, Jennifer/Rachel GIBBONS/Alexandra SUPPES/Robert KRAUSS (2012) "Phonetic convergence in college roommates." Journal of Phonetics 40, 190-197. http://dx.doi.org/10.1016/j.wocn.2011.10.001

PISKE, Thorsten/Ian MACKAY/James FLEGE (2001) "Factors affecting the degree of foreign accent in an L2: a review." Journal of Phonetics 29, 191-215. http://dx.doi. org/10.006/jpho.2001.0134

REINISCH, Eva/Andrea WEBER (2012) "Adapting to suprasegmental lexical stress errors in foreign-accented speech." Journal of the Acoustical Society of America 132, 1165-1176. http://dx.doi.org/10.1121/1.4730884

SAITO, Kazuya (2011) "Examining the role of explicit phonetic instruction in nativelike and comprehensible pronunciation development: an instructed SLA approach to L2 phonology." Language Awareness 20/1, 45-59. http://dx.doi.org/10.1080/09 658416.2010 .540326

SAITO, Kazuya (2012) "Effects of instruction on L2 pronunciation development: a synthesis of 15 quasi-experimental intervention studies." TESOL Quarterly 46/4, 842-854. http://dx.doi.org/10.1002/tesq.67

Studiegids Engels. 2014. Radboud University Nijmegen. http://www.studiegids. science.ru.nl/2014/arts/prospectus/engels/

SZPYRA-KOZŁOWSKA, Jolanta (2015) Pronunciation in EFL instruction: A research based approach. Bristol: Multilingual Matters.

UNDERHILL, Adrian (2013) "Cinderella, integration and the pronunciation turn." Speak out! IATEFL pronunciation special interest group newsletter 49. https:// adrianpronchart.files.wordpress.com/2013/12/adrian-cinderella_jmc.pdf

\section{Abstract \\ THE VALUE OF PHONETICS AND PRONUNCIATION TEACHING FOR ADVANCED LEARNERS OF ENGLISH}

Pronunciation is an essential part of acquiring a second language, but far too often little time is spent on teaching it (Kelly 1969). It seems as if it is generally thought that 
pronunciation is something that will develop on its own, yet learners are still assumed to maintain a certain level. This paper investigates the effects of explicit pronunciation and phonetics teaching on the English speech production of advanced Dutch learners of English. The pronunciation of advanced university learners was investigated at several points over a period of three years, halfway during which their pronunciation teaching was stopped. The effect this termination had on their speech production was investigated, as well as any task-specific differences in read versus spontaneous speech. Also studied was the potential influence of studying abroad and taking English-taught courses. Overall, this study shows that explicit teaching has a clear effect on the pronunciation of the learners. Some features of pronunciation turn out to be more robust than others, and the task type has an unmistakeable influence on the native-like quality of the learners' pronunciation, while there was only a minor effect of general exposure to English. Altogether, the value of explicit phonetics and pronunciation teaching turns out to be quite high for advanced second language learners, and once they acquire a certain level they are able to maintain a stable accent.

Keywords: EFL, phonetics, pronunciation, pronunciation teaching, pronunciation stability

Povzetek

\section{VREDNOST POUČEVANJA FONETIKE IN IZGOVARJAVE ZA NAPREDNE UČENCE ANGLEŠČINE}

Izgovarjava je ključni element učenja tujega jezika, vendar se njenemu poučevanju prepogosto posveča premalo časa (Kelly 1969). Zdi se, da velja prepričanje, da se bo izgovarjava sčasoma razvila kar sama od sebe, hkrati pa se pričakuje, da bodo učenci vendarle dosegli določen nivo. Članek obravnava učinke eksplicitnega poučevanja izgovarjave in fonetike na tvorjenje angleškega govora pri naprednih nizozemskih učencih angleščine. V obdobju treh let se je izgovarjava pri naprednih študentih večkrat preverjala. Sredi triletnega obdobja pa se je poučevanje izgovarjave prenehalo. Ugotavljali smo, kako je prekinitev poučevanja izgovarjave vplivala na tvorjenje govora in ali je bilo moč opaziti specifične razlike med branjem in spontanim govorom. Upoštevali smo tudi vpliv študija $v$ tujini in spremljanja predavanj $v$ angleškem jeziku. Naša študija dokazuje, da ima eksplicitno poučevanje izgovarjave jasen učinek na razvoj le-te pri učencih. Nekatere izgovorne značilnosti so bolj izrazite kot druge, prav tako tudi vrsta naloge nedvomno vpliva na podobnost učenčeve izgovarjave izgovarjavi rojenih govorcev. Količina izpostavljenosti angleščini ima manjši učinek na izgovarjavo. Vrednost eksplicitnega poučevanja fonetike in izgovarjave je pri naprednih učencih tujega jezika precej visoka. Ko enkrat dosežejo določen nivo, so ga sposobni tudi ohraniti.

Ključne besede: angleščina kot tuji jezik, fonetika, izgovarjava, poučevanje izgovarjave, stabilnost izgovarjave 